\title{
Propoxyphene Napsylate
}

National Cancer Institute

\section{Source}

National Cancer Institute. Propoxyphene Napsylate. NCI Thesaurus. Code C29386.

A synthetic diphenyl propionate derivative structurally related to methadone,

Propoxyphene Napsylate acts as a central narcotic and analgesic agent by interaction with mu opioid receptors, but with less selectivity then morphine. The dextro-isomer has analgesic effect, while the levo-isomer exerts an antitussive effect. The napsylate salt allows better dosage formulation than the hydrochloride salt. (NCI04) 